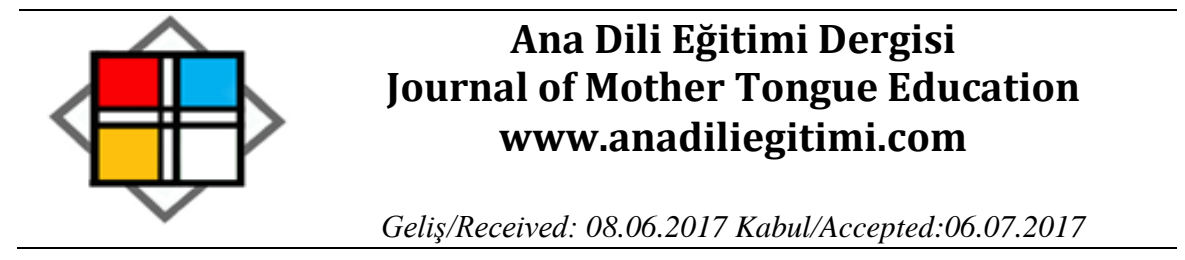

\title{
Yabancılara Türkçe Öğretimindeki Ders Kitaplarındaki Okuma Metinlerinin Bilgi Türleri Açısından İncelenmesi ( İstanbul C1/+ Örneği)
}

\author{
Esra Nur TIRYAKi* \\ Seyit Ömer DOĞAN**
}

Öz

Araştırmanın amacı, istanbul C1/+ Yabancılar Için Türkçe Ders Kitabı'ndaki okuma metinlerinin bilgi türleri yönünden incelenmesidir. Çalışma, var olan bir durumu ortaya koyma açısından betimsel tarama modelindedir. Araştırma, istanbul C1/+ Yabancılar Için Türkçe Ders Kitabı'nda bulunan okuma metinleri ile gerçekleştirilmiştir. Bu metinler, içerik analizi yöntemiyle bilgi zenginliği, türleri açısından incelenmiş ve altı kategoriye göre kodlanmıştır. Elde edilen veriler, betimsel istatistiki teknikler ile tablolaştırılmıştır. Yapılan analizlere göre istanbul C1/+ Yabancılar için Türkçe Ders Kitabı'ndaki okuma metinlerinde 1499 bilgi tespit edilmiştir. Üniteler arası yapılan değerlendirmeye göre bilgi miktarı açısından üniteler arasında büyük farkıııkların olmadığı görülmüştür. Bilgi sayıları bakımından en fazla bilgi zenginliği olan birinci ünite ( $f=186)$ ve ikinci ünitedir ( $f=163$ ). Bilgi zenginliği açısından zayıf olan on birinci $(f=77)$ ve dördüncü $(f=74)$ ünitedir. Bilgi türleri açısından değerlendirildiğinde gündelik bilgi $(n=458)$, bilimsel bilgi $(n=405)$ en fazla; en az dini bilgi $(n=28)$ ve teknik bilgi $(n=25)$ tespit edilmiştir. En fazla bilgi açısından zengin olan metin "Esaretin Bedeli" ( $n=78)$ iken, bilgi zenginliği zayıf olan metin $(n=12)$ ise "Arzuhalden Dilekçeye" dir.

Anahtar Kelimeler: Bilgi, bilgi türleri, yabancılara Türkçe öğretimi, ders kitabı

\section{Examination of Reading Texts in Terms of Types of Information in Turkish as a Foreign Language Course Books (Example of i̇stanbul C1/+ Course Book)}

\begin{abstract}
The purpose of this research is to examine the reading texts in the Istanbul C1 / + Turkish Course Book for Foreigners in terms of types of information. The study utilizes the descriptive research model which is used to depict a situation that already exists. The research was carried out with the reading texts found in the Istanbul C1 / + Turkish Course Book for Foreigners. The texts were examined in terms of information richness and types, using content analysis and were coded for six categories. The obtained data were tabulated, using descriptive statistics techniques. According to the analysis made, 1499 pieces of information were identified in the reading texts of the Istanbul C1 / + Turkish Course Book for Foreigners. According to the evaluation made among the units, there was no significant difference among the units in terms of amount of information. In terms of information count, the first unit $\quad(f=186)$ and the second unit $(f=163)$ had the greatest wealth of information. The eleventh $(f=77)$ and the fourth $(f=74)$ units were the weakest in terms of information wealth. When the course book was evaluated in terms of information types, daily knowledge $(n=458)$ and scientific knowledge $(n=405)$ were the most frequent; religious knowledge $(n=28)$ and technical knowledge $(n=25)$ were the least frequent.
\end{abstract}

\footnotetext{
${ }^{*}$ Yrd. Doç. Dr., Mustafa Kemal Üniversitesi Eğitim Fakültesi Türkçe Ve Sosyal Bilimler Bölümü, Türkçe Eğitimi ABD, Hatay. e-posta: esranurtiryaki@gmail.com

${ }^{* *}$ Yüksek Lisans Öğrencisi, Mustafa Kemal Üniversitesi, Sosyal Bilimler Enstitüsü, Türkçe Eğitimi ABD, Hatay. eposta: seyitomerdogan01@gmail.com
} 
In terms of information richness, the richest text is "Esaretin Bedeli" $(n=78)$ while the poorest text is "Arzuhalden Dilekçeye" ( $\mathrm{n}=12)$.

Keywords: Information, Types of information, Teaching Turkish to Foreigners, course book

\section{Giriş}

Dil, o milletin kültür tablosunun aktarımında önemli bir araçtır. Akarsu (1998: 80) bu konuda, dil yaşamın bütün alanlarında, günlük yaşamın en yalın olaylarında, bilimin ana formlarında, görenekler ve törelerde, inançlarda ortaya çıkar; dil her türlü maddesel yaşamın, tekniğin, ekonominin de koşuludur; dinde, hukukta, felsefe ve sanatta yeri vardır. Yabancılara dil eğitimi ve öğretiminde kültür ve bilgi önemli bir kavramdır. Çünkü dil öğretimi dizge içerisinde anlam kazanan göstergeler arasındaki ilişkiler ağını örtük bilgiden açık bilgiye, açık bilgiden dil farkındalığına ve nihayetinde işlevsel dil kullanımına dönüştürmeyi hedefler (Onan, 2013: 79). Dil kullanımında, kişi kendisinden var olan eski bilgiyle kaynaklardan aldığı yeni bilgileri akıl süzgecinden geçirerek doğru bilgiye ulaşır. Bilgi kavramı özne ile nesne arasında gerçekleşen iletişim sürecinin sonucudur. Epistemolojiye göre bilgilerin elde ediliş biçimleri ve özelliklerine göre bilgi türleri altı kategoride ele alınır. Epistemolojiye göre bilgi türleri (Bolay, 2007; Çüçen, 2009; Tunalı 2009; Cevizci, 2010) gündelik bilgi, teknik bilgi, dinî bilgi, sanat bilgisi, bilimsel bilgi ve felsefî bilgidir.

Gündelik bilgiler, bilimsel temellere dayanmayan günlük yaşam ile ilgili ipuçları sunan bilgi türüdür. Gündelik bilgiyi, pratik bilgi (Çüçen, 2009: 18), somut olan her şey (Cevizci, 2010: 49) olarak da tanımlayabiliriz. Teknolojinin ilerlemesi ile hayatımıza giren teknik araç gereçler ve bunların kullanılmasıyla ilgili bilgilerimiz teknik bilgi sınıfında değerlendirilir. Bu bilgi türü nesneldir. El ve zihin becerisi olarak iki alanda incelenir (Tunalı, 2009: 17). Bir tornavida yardımıyla bir dolabın kurulumunun yapılması veya televizyon tamiri bu bilgi türüne girer. Doğayı, kendi yaratılışını, gökyüzünü, yıldızları; kısaca gördüğü her şeyi anlamaya çalışan insanoğlu, bir yaratıca inanmayı tercih etmiş ve tüm bunları yarattığını düşündüğü bir “Tanrı”ya inanmıştır. Yüzyıllar boyunca insanlar çeşitli dinlere inanmışlardır. İşte, bu dinlerle ilgili bilgilerimiz dinî bilgileri oluşturur. " Özne ve nesne arasındaki bağ, yüce bir varlık (Tanrı) tarafından belirlenen bir inanç sistemine dayanarak elde ediliyorsa, bu tür bilgiye dinsel bilgi denir" (Çüçen, 2009: 19). Insanlar ve çevrelerindeki varlıklar arasındaki estetik ve güzellik anlayışı sanatsal bilgiyi oluşturur. "Sanat da aynen teknik gibi, belli bir yaratma faaliyeti olarak ortaya çıkar. Fakat sanattaki yaratma faaliyeti, insan için yararlı amaçlar üretmeyi amaçlamaz; o, esas olarak güzellik yaratmayı amaçlar" (Cevizci, 2010: 50). Sanatçılara göre gördükleri şeyler sanatın kuralları çerçevesinde değer kazanır. "Bilimsel bilgi, sınırlı bir konusu ve belli bir yöntemi olan; sistemli ve genel geçer sonuçlara ulaşmak isteyen ve konusuna 'bilmek için bilmek' amacıyla yönelen bir bilgidir" (Tunalı, 2009: 19). Bilimsel bilgiler, merak ve dünyayı keşfetme isteğinden doğan bilgilerdir. "Felsefe bilgisi, evrenin ve insan yaşamının anlamının ne olduğu ile ilgili 
Yabancılara Türkçe Öğretimindeki Ders Kitaplarındaki Okuma Metinlerinin Bilgi Türleri Açısından İncelenmesi ( İstanbul C1/+ Örneği)

sorularla ortaya çıkar" (Tunalı, 2009: 23). Felsefi bilgiler akla dayanırken, dini bilgilerin doğaüstü düşüncelere dayanmadı aralarındaki temel farktır. Felsefi bilgiler sorgulamaya açıktır.

Eğitim öğretim ortamlarında bilgi, öğrenci ile öğretmen arasında, öğrenci ile ders kitabı, öğrenci ve öğrenci arasında sürekli hareket etmektedir (Onan, 2013: 47). Bundan dolayı ders kitapları bilgi aktarımında önemli bir araçtır. Yabancılara dil öğretiminde ders kitaplarında yer alan okuma ve dinleme metinleri bilgi çerçevesinde değerlendirilmelidir. Çünkü bilgi ile birlikte kültür aktarımı ve toplumsal değerler kişilerde oluşturulmaktadır. Bayyurt ve Yaylı (2014)'e göre yabancı dil öğrenmek her şeyden önce yeni bir dünyaya kapılarını açmak, yeni yerler görmek, yeni insanlar ve kültürlerle tanışmak, tanıdık kavramlara ve düşüncelere değişik açılardan bakmak ve yeni deneyimler edinmektir.

Yabancı dil öğretimi için hazırlanan kitapların temel amacı Türkçe öğretimi olsa da bu kitaplar Türkçenin zenginliklerini, Türk kültürünü ve çeşitli bilgileri de yeterince ihtiva etmelidir. Öğrenciler Türk dilini öğrenirlerken çeşitli bilgiler de edinerek geleceğe daha donanımlı ve bilgili bir şekilde ilerlemelidirler.

Yabancılara Türkçe öğretimi sadece dil becerilerinin öğretiminden ibaret değildir. Bu becerilerle kişilere aktarılan bilgiler de önemlidir. Çünkü bilgi aktarımı ile insan kişilik ve kimlik kazanmaktadır. Türkçeyi yabancı dil olarak öğrenen öğrencilerin dört temel dil becerisinin yanında bu becerileri kullanarak ifade edecekleri (konuşma ve yazma) ve anlayacakları (okuma ve dinleme) bilgilerle bol bol karşılaşmaları son derece önemlidir. Öğrenci, ilgisini çekecek ve kendisinde merak duygusu uyandıracak bilgileri zevkle öğrenirken ve bunları başkalarına aktarırken bu sayede Türkçe derslerine ve Türk dilini öğrenmeye karşı da olumlu bir tutum geliştirecektir. Bütün bu sebepler düşünüldüğünde bu araştırma, İstanbul Üniversitesi'nin yabancılara Türkçe öğretiminde kullanılması için hazırlamış olduğu İstanbul C1/+ Yabancılar İ̧̧in Türkçe Ders Kitabı'ndaki okuma metinlerin bilgi türleri yönünden incelemeyi amaçlamaktadır.

\section{Yöntem}

Bu bölümde araştırmanın modeli, evren ve örneklemi, veri toplama araçları, verilerin toplanması ve çözümlenmesi ile ilgili bilgiler bulunmaktadır.

\section{Araştırmanın Modeli}

$\mathrm{Bu}$ araştırma, tarama modelinde betimsel bir çalışmadır. Araştırma nitel veri toplama tekniklerinden faydalanılarak gerçekleştirilmiştir. Betimsel tarama modeli olayların, objelerin, varlıkların, kurumların, grupların ve çeşitli alanların ne olduğunu betimlemeye, açıklamaya çalışır. Bu sayede onları iyi anlayabilme, gruplayabilme olanağı sağlanır ve aralarındaki ilişkiler saptanmış olur (Kaptan, 1998). 


\section{Çalışma Grubu}

$\mathrm{Bu}$ araştırmanın çalışma grubunu yabancılara Türkçe öğretiminde kullanılan istanbul C1/+ Yabancılar İ̧in Türkçe Ders Kitabı'ndaki okuma metinleri oluşturmaktadır. Dinleme metinleri, "kültürden kültüre" metinleri ve "medeniyetimize yön verenler" metinleri araştırmaya alınmamıştır. Bilgiler bulunurken bazen tek bir cümle alınmış, bazense anlamın birden fazla cümlede tamamlandığı cümleler tek bir bilgi olarak kabul edilmiştir. Aşağıda Tablo 1'de, araştırmanın çalışma grubunu oluşturan kitap, bu kitaptaki metin, cümle ve bilgi sayısı verilmiştir.

Tablo 1. Araştırmanın çalışma grubunu oluşturan kitap, bu kitaptaki metin, cümle ve bilgi sayısı

\begin{tabular}{llll}
\hline Kitabın Adı & Metin (f) & Cümle(f) & Bilgi (n) \\
\hline İstanbul Yabancılar İçin Türkçe Ders Kitabı C1/+ & 36 & 1611 & 1499 \\
\hline
\end{tabular}

\section{Veri Toplama Araçları}

Araştırmanın verileri, araştırmacı ve bir uzman tarafından İstanbul C1/+ seviyesindeki ders kitabındaki okuma metinleri bilgi türleri açsından incelenerek bir forma kaydedilmiştir. Bu form ile metinler daha sonra 3 uzmana daha gösterilerek bilgi türleri açısından fikir birliği sağlanmıştır.

\section{Veri Analiz Yöntemi}

Araştırma kapsamında elde edilen verileri betimsel istatistiki tekniklere göre (frekans ve yüzde) analiz edilip tablolar ve örnek cümlelerle sunulmuştur.

\section{Bulgular}

Bu bölümde Yabancılara Türkçe Eğitimi Dersi kitaplarından İstanbul Serisi C1/+ seviyesinde yer alan metinlerdeki cümle ve bilgi sayıları ayrıntılı olarak tablolaştırılmış, frekans ve yüzdeleri hesaplanarak değerlendirilmiştir. Ayrıca bilgi türlerinin her biri için ayrı tablolar oluşturulmuş ve bunlar detaylı olarak incelenmiştir.

Aşağıdaki tabloda İstanbul C1/+ Yabancılar İçin Türkçe Ders Kitabı'ndaki tüm metinlere ait cümle sayıları ve toplam bilgi sayıları frekans (f) ve yüzdelerle (\%) verilmiştir.

Tablo 2. Ders kitabındaki tüm metinlere ve ünitelere göre cümle bilgi frekans(f) ve yüzdeleri (\%)

\begin{tabular}{lllllll}
\hline No & Ünite & Metin & $\begin{array}{l}\text { Cümle } \\
\text { (f) }\end{array}$ & $\begin{array}{l}\text { (Yüzde) } \\
\text { \% }\end{array}$ & $\begin{array}{l}\text { Bilgi } \\
\text { (n) }\end{array}$ & $\begin{array}{l}\text { Yüzde } \\
\text { (\%) }\end{array}$ \\
\hline $\mathbf{1}$ & 1 & Saatin İcadı & 49 & 3,04 & 66 & 4,40 \\
$\mathbf{2}$ & 1 & 24 Saat Yetmiyorsa & 58 & 3,60 & 62 & 4,13 \\
$\mathbf{3}$ & 1 & Ünlü Bilim Adamlarının Çocuklukları & 48 & 2,97 & 58 & 3,86 \\
$\mathbf{4}$ & $\mathbf{2}$ & Aşkın Kimyası & 49 & 3,04 & 46 & 3,06 \\
$\mathbf{5}$ & $\mathbf{2}$ & Ünlü Aşıklar ve Aşk Mektupları & 55 & 3,41 & 52 & 3,46 \\
$\mathbf{6}$ & $\mathbf{2}$ & Aşkın Sırrı & 99 & 6,14 & 65 & 4,33 \\
$\mathbf{7}$ & 3 & Büyük ikramiyeyi kazanıp sonra kaybedenler & 42 & 2,60 & 44 & 2,93 \\
$\mathbf{8}$ & 3 & Satranç ve Tavla & 33 & 2,04 & 30 & 2,00 \\
$\mathbf{9}$ & $\mathbf{3}$ & Elmas Gerdanlık & 111 & 6,89 & 45 & 3,00 \\
$\mathbf{1 0}$ & $\mathbf{4}$ & Arzuhalden Dilekçeye & 12 & 0,74 & 12 & 0,80 \\
\hline
\end{tabular}


Yabancılara Türkçe Öğretimindeki Ders Kitaplarındaki Okuma Metinlerinin Bilgi Türleri Açısından İncelenmesi ( İstanbul C1/+ Örneği)

\begin{tabular}{|c|c|c|c|c|c|c|}
\hline 11 & 4 & $\begin{array}{l}\text { İş Görüşmelerinde İş Verenler Nelere Dikkat } \\
\text { Eder? }\end{array}$ & 30 & 1,86 & 34 & 2,26 \\
\hline 12 & 4 & Fatih Sultan Mehmet Mahkemede & 22 & 1,36 & 28 & 1,86 \\
\hline 13 & 5 & Lumiere Kardeşler & 37 & 2,29 & 51 & 3,40 \\
\hline 14 & 5 & Susuz Yaz & 102 & 6,33 & 33 & 2,20 \\
\hline 15 & 5 & Yabancı Ülkelerde Yayınlanan Türk Dizileri & 28 & 1,73 & 69 & 4,60 \\
\hline 16 & 6 & Bilge ve Bilgelik & 61 & 3,78 & 26 & 1,73 \\
\hline 17 & 6 & Bilgi Teknolojisi & 24 & 1,48 & 48 & 3,20 \\
\hline 18 & 6 & Bilgi Toplumu ve Üniversiteler & 44 & 2,73 & 66 & 4,40 \\
\hline 19 & 7 & Sanat Nedir? & 42 & 2,60 & 27 & 1,80 \\
\hline 20 & 7 & Sanat Türleri & 34 & 2,11 & 57 & 3,80 \\
\hline 21 & 7 & Türk Süsleme Sanatları & 49 & 3,04 & 37 & 2,46 \\
\hline 22 & 8 & Suç Nedir? & 41 & 2,54 & 26 & 1,73 \\
\hline 23 & 8 & Adalet Nedir? & 31 & 1,92 & 41 & 2,73 \\
\hline 24 & 8 & Esaretin Bedeli & 74 & 4,59 & 78 & 5,20 \\
\hline 25 & 9 & Mizah Her Kapıyı Açar & 60 & 3,72 & 68 & 4,53 \\
\hline 26 & 9 & Mizah Türleri & 29 & 1,80 & 21 & 1,40 \\
\hline 27 & 9 & Hasan Kaçan & 14 & 0,86 & 13 & 0,86 \\
\hline 28 & 10 & Dünden Bugüne Para & 48 & 2,97 & 41 & 2,73 \\
\hline 29 & 10 & Türkiye'de Enflasyonun Tarihi Gelişimi & 24 & 1,48 & 26 & 1,73 \\
\hline 30 & 10 & Öğrenciler İçin Tasarruf Yöntemleri & 46 & 2,85 & 47 & 3,13 \\
\hline 31 & 11 & Dünyamız & 25 & 1,55 & 27 & 1,80 \\
\hline 32 & 11 & Küresel Isınma Nedir? & 21 & 1,30 & 22 & 1,46 \\
\hline 33 & 11 & Dünya'dan Mars'a & 26 & 1,61 & 28 & 2,93 \\
\hline 34 & 12 & Gençlerin Medya Tüketimi & 32 & 1,98 & 44 & 2,93 \\
\hline 35 & 12 & Mert'in İletişim Serüveni & 77 & 4,77 & 35 & 2,33 \\
\hline 36 & 12 & Internet ve Sosyal Medya Bağımlılığı & 34 & 2,11 & 26 & 1,73 \\
\hline Toplam & & & 1611 & 100 & 1499 & 100 \\
\hline
\end{tabular}

Tablo 2'ye göre Istanbul C1/+ Yabancılar İçin Türkçe Ders Kitabı'nda toplam 12 ünite ve 36 okuma metni bulunmaktadır. Ayrıca söz konusu kitaptaki metinlerde araştırmacı tarafından toplam 1611 cümle tespit edilmiş olup bu cümlelerde 1499 adet bilgi bulunmuştur. Bilgiler bulunurken bazen tek bir cümle alınmış, bazense anlamın birden fazla cümlede tamamlandığı cümleler tek bir bilgi olarak kabul edilmiştir. Tabloya bakıldığında en fazla cümle (111 cümle, \%6,89) “Elmas Gerdanlık” adlı metinde; en az cümle ise "Küresel Isınma" Nedir? (21 cümle, \%1,30)adlı metindedir.

Yine tablodaki bilgilere göre en çok bilgi zenginliği bulunduran metnin 8. ünitede yer alan "Esaretin Bedeli" adlı metin olduğunu (78 bilgi, \%5,20); en az bilgi bulunduran metnin 4. ünitede yer alan "Arzuhalden Dilekçeye" adlı metin olduğunu $(12$ bilgi, \%0,80) tespit edilmiştir. Ünitelere göre cümle sayıları değerlendirildiğinde, 2. ünitenin cümle sayısı bakımından en zengindir. 2. ünitede 203 adet cümle tespit edilmiştir. 2. ünitedeki cümle sayısının tüm kitaptaki cümlelerin sayısına oranı ise \%12,60 olarak hesaplanmıştır. Ünitelere göre bilgi sayıları değerlendirildiğinde ise 1 . ünitenin bilgi sayısı bakımından en zengin ünite olduğu söylenebilir. 1. ünitede toplam 186 adet bilgi tespit edilmiştir. 1. Ünitedeki bilgi sayısının tüm kitaptaki bilgilerin sayısına oranı ise \%12,40 olarak hesaplanmıştır. Aşağıdaki Tablo 3'te İstanbul C1/+ Yabancılar İçin Türkçe Ders Kitabı'nda bulunan okuma metinlerindeki bilimsel bilgi sayısı, frekans (f) ve yüzdelerle (\%) verilmiştir. 
Tablo 3. Istanbul C1/+ Yabancılar İçin Türkçe Ders Kitabı'nda bulunan okuma metinlerindeki bilimsel bilgi sayısı, frekansları (f) ve yüzdeleri (\%)

\begin{tabular}{|c|c|c|c|c|}
\hline No & Ünite & Metin & Bilimsel bilgi sayısı (n) & Yüzde(\%) \\
\hline 1 & 1 & Saatin İcadı & 45 & 11,11 \\
\hline 2 & 1 & 24 Saat Yetmiyorsa & 0 & 0 \\
\hline 3 & 1 & Ünlü Bilim Adamlarının Çocuklukları & 35 & 8,64 \\
\hline 4 & 2 & Aşkın Kimyası & 29 & 7,16 \\
\hline 5 & 2 & Ünlü Aşıklar ve Aşk Mektupları & 4 & 0,98 \\
\hline 6 & 2 & Aşkın Sırrı & 5 & 1,23 \\
\hline 7 & 3 & $\begin{array}{l}\text { Büyük ikramiyeyi kazanıp sonra } \\
\text { kaybedenler }\end{array}$ & 2 & 0,49 \\
\hline 8 & 3 & Satranç ve Tavla & 11 & 2,71 \\
\hline 9 & 3 & Elmas Gerdanlık & 0 & 0 \\
\hline 10 & 4 & Arzuhalden Dilekçeye & 2 & 0,49 \\
\hline 11 & 4 & $\begin{array}{l}\text { İş Görüşmelerinde İş Verenler Nelere } \\
\text { Dikkat Eder? }\end{array}$ & 0 & 0 \\
\hline 12 & 4 & Fatih Sultan Mehmet Mahkemede & 7 & 1,72 \\
\hline 13 & 5 & Lumiere Kardeşler & 11 & 2,71 \\
\hline 14 & 5 & Susuz Yaz & 7 & 1,72 \\
\hline 15 & 5 & $\begin{array}{l}\text { Yabancı Ülkelerde Yayınlanan Türk } \\
\text { Dizileri }\end{array}$ & 12 & 2,96 \\
\hline 16 & 6 & Bilge ve Bilgelik & 7 & 1,72 \\
\hline 17 & 6 & Bilgi Teknolojisi & 18 & 4,44 \\
\hline 18 & 6 & Bilgi Toplumu ve Üniversiteler & 21 & 5,18 \\
\hline 19 & 7 & Sanat Nedir? & 3 & 0,74 \\
\hline 20 & 7 & Sanat Türleri & 0 & 0 \\
\hline 21 & 7 & Türk Süsleme Sanatları & 17 & 4,19 \\
\hline 22 & 8 & Suç Nedir? & 19 & 4,69 \\
\hline 23 & 8 & Adalet Nedir? & 1 & 0,24 \\
\hline 24 & 8 & Esaretin Bedeli & 1 & 0,24 \\
\hline 25 & 9 & Mizah Her Kapıyı Açar & 9 & 2,22 \\
\hline 26 & 9 & Mizah Türleri & 2 & 0,49 \\
\hline 27 & 9 & Hasan Kaçan & 0 & 0 \\
\hline 28 & 10 & Dünden Bugüne Para & 25 & 6,17 \\
\hline 29 & 10 & Türkiye'de Enflasyonun Tarihi Gelişimi & 13 & 3,20 \\
\hline 30 & 10 & Öğrenciler İçin Tasarruf Yöntemleri & 1 & 0,24 \\
\hline 31 & 11 & Dünyamız & 25 & 6,17 \\
\hline 32 & 11 & Küresel Isınma Nedir? & 19 & 4,69 \\
\hline 33 & 11 & Dünya'dan Mars'a & 22 & 5,43 \\
\hline 34 & 12 & Gençlerin Medya Tüketimi & 27 & 6,66 \\
\hline 35 & 12 & Mert'in İletişim Serüveni & 1 & 0,24 \\
\hline 36 & 12 & İnternet ve Sosyal Medya Bağımlılığı & 4 & 0,98 \\
\hline Toplam & & & 405 & 100 \\
\hline
\end{tabular}

Tablo 3 incelendiğinde İstanbul C1/+ Yabancılar İçin Türkçe Ders Kitabı'nda toplam 405 adet bilimsel bilgi tespit edilmiştir. Buna göre bilimsel bilgilerin oranı tüm bilgilerin \%27,01'lik kısmını oluşturmuştur. 1. ünitede yer alan "Ünlü Bilim Adamlarının Çocuklukları" adlı metin, Tablo 3'e göre en fazla bilimsel bilgi içeren metindir (35 bilgi, \%8,64). 1. ünitede yer alan "24 Saat Yetmiyorsa", 4. ünitede yer alan "iş̧ Görüşmelerinde iş Verenler Nelere Dikkat Eder?", 7. ünitede yer alan "Sanat Türleri", 9. ünitede yer alan "Hasan Kaçan" adlı metinlerde hiç bilimsel bilgiye rastlanmadığı görülmektedir. 
Yabancılara Türkçe Öğretimindeki Ders Kitaplarındaki Okuma Metinlerinin Bilgi Türleri Açısından İncelenmesi ( İstanbul C1/+ Örneği)

Ünitelere göre bilimsel bilgi sayıları değerlendirildiğinde 1. ünitenin 80 adet $(\% 19,75)$ bilimsel bilgi ile en fazla bilimsel bilgi içeren ünite olduğu belirlenmiştir.

Okuma metinlerindeki bilimsel bilgilere birkaç örnek:

- 1860'tan günümüze kadar tutulan kayıtlar, ortalama küresel sıcaklığın 0,5 ila 0,8 derece kadar arttığını gösteriyor. (s.181, Küresel Isınma Nedir?)

- Gerçekleştirilen güncel bir çalışma uzun süre yerçekimsiz ortamda kalmanın kas dokusunu zedelediği ve fiziksel kapasiteyi \%40’tan fazla azalttığını gösteriyor. (s. 185, Dünya'dan Mars'a)

- Araştırma çerçevesinde tam 4 bin 300 online ve yüz yüze anket yapılırken 16 grup tartışması gerçekleştirilmiş. (s. 192, Gençlerin Medya Tüketimi)

- Zamanı ölçmek için ilk çabalar güneş saatiyle başlamıştır. (s. 10, Saatin İcadı)

- Gymnasium Antik Yunanca ve Latinceye büyük önem veriyordu. (s. 21, Ünlü Bilim Adamlarının Çocuklukları)

Aşağıdaki Tablo 4'te İstanbul C1/+ Yabancılar İçin Türkçe Ders Kitabı'nda bulunan okuma metinlerindeki felsefî bilgi sayısı, frekans (f) ve yüzdelerle(\%) verilmiştir.

Tablo 4. İstanbul C1/+ Yabancılar İçin Türkçe Ders Kitabı'nda bulunan okuma metinlerindeki felsefí bilgi sayısı, frekansları (f) ve yüzdeleri (\%)

\begin{tabular}{|c|c|c|c|c|}
\hline No & Ünite & Metin & Felsefî bilgi sayısı (n) & Yüzde(\%) \\
\hline 1 & 1 & Saatin İcadı & 1 & 0,29 \\
\hline 2 & 1 & 24 Saat Yetmiyorsa & 20 & 5,81 \\
\hline 3 & 1 & Ünlü Bilim Adamlarının Çocuklukları & 8 & 2,32 \\
\hline 4 & 2 & Aşkın Kimyası & 14 & 4,06 \\
\hline 5 & 2 & Ünlü Aşıklar ve Aşk Mektupları & 21 & 6,10 \\
\hline 6 & 2 & Aşkın Sırrı & 29 & 8,43 \\
\hline 7 & 3 & $\begin{array}{l}\text { Büyük ikramiyeyi kazanıp sonra } \\
\text { kaybedenler }\end{array}$ & 12 & 3,48 \\
\hline 8 & 3 & Satranç ve Tavla & 8 & 2,32 \\
\hline 9 & 3 & Elmas Gerdanlık & 8 & 2,32 \\
\hline 10 & 4 & Arzuhalden Dilekçeye & 1 & 0,29 \\
\hline 11 & 4 & $\begin{array}{l}\text { İş Görüşmelerinde İş Verenler Nelere } \\
\text { Dikkat Eder? }\end{array}$ & 15 & \\
\hline 12 & 4 & Fatih Sultan Mehmet Mahkemede & 1 & 0,29 \\
\hline 13 & 5 & Lumiere Kardeşler & 15 & 4,36 \\
\hline 14 & 5 & Susuz Yaz & 10 & 2,90 \\
\hline 15 & 5 & $\begin{array}{l}\text { Yabancı Ülkelerde Yayınlanan Türk } \\
\text { Dizileri }\end{array}$ & 0 & 0 \\
\hline 16 & 6 & Bilge ve Bilgelik & 58 & 16,86 \\
\hline 17 & 6 & Bilgi Teknolojisi & 2 & 0,58 \\
\hline 18 & 6 & Bilgi Toplumu ve Üniversiteler & 20 & 5,81 \\
\hline 19 & 7 & Sanat Nedir? & 30 & 8,72 \\
\hline 20 & 7 & Sanat Türleri & 1 & 0,29 \\
\hline
\end{tabular}




\begin{tabular}{lllll}
\hline $\mathbf{2 1}$ & 7 & Türk Süsleme Sanatları & 0 & 0 \\
$\mathbf{2 2}$ & 8 & Suç Nedir? & 6 & 1,74 \\
$\mathbf{2 3}$ & 8 & Adalet Nedir? & 25 & $\mathbf{7 , 2 6}$ \\
$\mathbf{2 4}$ & 8 & Esaretin Bedeli & 1 & 0,29 \\
$\mathbf{2 5}$ & 9 & Mizah Her Kapıyı Açar & 29 & 8,43 \\
$\mathbf{2 6}$ & 9 & Mizah Türleri & 3 & 0,87 \\
$\mathbf{2 7}$ & 9 & Hasan Kaçan & 0 & 0 \\
$\mathbf{2 8}$ & 10 & Dünden Bugüne Para & 1 & 0,29 \\
$\mathbf{2 9}$ & 10 & Türkiye'de Enflasyonun Tarihi Gelişimi & 0 & 0 \\
$\mathbf{3 0}$ & 10 & Öğrenciler İçin Tasarruf Yöntemleri & 1 & 0,29 \\
$\mathbf{3 1}$ & 11 & Dünyamız & 0 & 0 \\
$\mathbf{3 2}$ & 11 & Küresel Isınma Nedir? & 0 & 0 \\
$\mathbf{3 3}$ & 11 & Dünya'dan Mars'a & 0 & 0 \\
$\mathbf{3 4}$ & 12 & Gençlerin Medya Tüketimi & 1 & 0,29 \\
$\mathbf{3 5}$ & 12 & Mert'in Illetişim Serüveni & 3 & 0,87 \\
$\mathbf{3 6}$ & 12 & Internet ve Sosyal Medya Bağımlılı̆̆ & 0 & 0 \\
Toplam & & & $\mathbf{3 4 4}$ & $\mathbf{1 0 0}$ \\
\hline
\end{tabular}

Tablo 4 incelendiğinde 344 adet felsefî bilgi tespit edilmiştir. Buna göre felsefî bilgilerin tüm bilgilere oranı \%22,94'tür.

Tablo 4. incelendiğinde 6. ünitede yer alan "Bilge ve Bilgelik" adlı metnin en fazla felsefî bilgi içeren metin olduğu (58 felsefi bilgi, \%16,86) görülmektedir. 5. ünitede yer alan "Yabancı Ülkelerde Yayınlanan Türk Dizileri", 7. ünitede yer alan "Türk Süsleme Sanatları", 9. ünitede yer alan "Hasan Kaçan", 10. ünitede yer alan "Türkiye'de Enflasyonun Tarihi Gelişimi", 11. ünitede yer alan "Dünyamız", "Küresel Isınma Nedir?", "Dünya'dan Mars'a", 12. ünitede yer alan "internet ve Sosyal Medya Bağımlıı̆̆ı" adlı metinlerde hiç felsefî bilginin bulunmadığı görülmektedir. Ünitelere göre bilimsel bilgi sayıları değerlendirildiğinde 6 . ünitenin 80 adet $(\% 23,25)$ felsefî bilgi ile en fazla felsefî bilgi içeren ünite olduğu tespit edilmiştir.

Okuma metinlerindeki felsefî bilgilere birkaç örnek:

- Bilge, iç çalkantılardan ve ihtiraslardan arınmasını bilen akıllı bir kişidir (s.100, Bilge ve Bilgelik).

- Bu haldeki insan, her şeyin insan için olduğunu fark eder. (s. 100, Bilge ve Bilgelik)

- Bu anlayışa en uygun tanımı yapan Thomas Munro'ya göre sanat, "doyurucu estetik yaşantılar oluşturmak amacıyla dürtüler yaratma becerisidir." (s.116, Sanat Nedir?)

- Kendi içinde tutarlı bir bütünlüğü taşıyan şey çirkin, acı verici, iğrendirici bile olsa estetik açıdan güzeldir. (s.116, Sanat Nedir?)

- Hepimiz ergenlik yıllarımızdan başlayarak kendi kimliğimizi oluştururken adına ego dediğimiz kaleler inşa edip içine varlığımızı gizliyoruz. (s.144, Mizah Her Kapıyı Açar) 
Yabancılara Türkçe Öğretimindeki Ders Kitaplarındaki Okuma Metinlerinin Bilgi Türleri Açısından İncelenmesi ( İstanbul C1/+ Örneği)

Aşağıdaki Tablo 5'te İstanbul C1/+ Yabancılar İçin Türkçe Ders Kitabı'nda bulunan okuma metinlerindeki dinî bilgi sayısı, frekans (f) ve yüzdelerle (\%) verilmiştir.

Tablo 5. Istanbul C1/+ Yabancılar İçin Türkçe Ders Kitabı'nda bulunan okuma metinlerindeki dinî bilgi sayısı, frekansları (f) ve yüzdeleri (\%)

\begin{tabular}{|c|c|c|c|c|}
\hline No & Ünite & Metin & Dinî bilgi sayısı (n) & Yüzde(\%) \\
\hline 1 & 1 & Saatin İcadı & 0 & 0 \\
\hline 2 & 1 & 24 Saat Yetmiyorsa & 0 & 0 \\
\hline 3 & 1 & Ünlü Bilim Adamlarının Çocuklukları & 1 & 3,57 \\
\hline 4 & 2 & Aşkın Kimyası & 0 & 0 \\
\hline 5 & 2 & Ünlü Aşıklar ve Aşk Mektupları & 1 & 3,57 \\
\hline 6 & 2 & Aşkın Sırrı & 0 & 0 \\
\hline 7 & 3 & $\begin{array}{l}\text { Büyük ikramiyeyi kazanıp sonra } \\
\text { kaybedenler }\end{array}$ & 1 & 3,57 \\
\hline 8 & 3 & Satranç ve Tavla & 0 & 0 \\
\hline 9 & 3 & Elmas Gerdanlık & 0 & 0 \\
\hline 10 & 4 & Arzuhalden Dilekçeye & 2 & 7,14 \\
\hline 11 & 4 & $\begin{array}{l}\text { İş Görüşmelerinde iş Verenler Nelere } \\
\text { Dikkat Eder? }\end{array}$ & 0 & 0 \\
\hline 12 & 4 & Fatih Sultan Mehmet Mahkemede & 11 & 39,28 \\
\hline 13 & 5 & Lumiere Kardeşler & 0 & 0 \\
\hline 14 & 5 & Susuz Yaz & 2 & 7,14 \\
\hline 15 & 5 & Yabancı Ülkelerde Yayınlanan Türk Dizileri & 0 & 0 \\
\hline 16 & 6 & Bilge ve Bilgelik & 2 & 7,14 \\
\hline 17 & 6 & Bilgi Teknolojisi & 0 & 0 \\
\hline 18 & 6 & Bilgi Toplumu ve Üniversiteler & 0 & 0 \\
\hline 19 & 7 & Sanat Nedir? & 0 & 0 \\
\hline 20 & 7 & Sanat Türleri & 0 & 0 \\
\hline 21 & 7 & Türk Süsleme Sanatları & 4 & 14,28 \\
\hline 22 & 8 & Suç Nedir? & 2 & 7,14 \\
\hline 23 & 8 & Adalet Nedir? & 0 & 0 \\
\hline 24 & 8 & Esaretin Bedeli & 0 & 0 \\
\hline 25 & 9 & Mizah Her Kapıyı Açar & 1 & 3,57 \\
\hline 26 & 9 & Mizah Türleri & 0 & 0 \\
\hline 27 & 9 & Hasan Kaçan & 1 & 3,57 \\
\hline 28 & 10 & Dünden Bugüne Para & 0 & 0 \\
\hline 29 & 10 & Türkiye'de Enflasyonun Tarihi Gelişimi & 0 & 0 \\
\hline 30 & 10 & Öğrenciler İçin Tasarruf Yöntemleri & 0 & 0 \\
\hline 31 & 11 & Dünyamız & 0 & 0 \\
\hline 32 & 11 & Küresel Isınma Nedir? & 0 & 0 \\
\hline 33 & 11 & Dünya'dan Mars'a & 0 & 0 \\
\hline 34 & 12 & Gençlerin Medya Tüketimi & 0 & 0 \\
\hline 35 & 12 & Mert'in İletişim Serüveni & 0 & 0 \\
\hline 36 & 12 & İnternet ve Sosyal Medya Bağımlılığı & 0 & 0 \\
\hline Toplam & & & 28 & 100 \\
\hline
\end{tabular}

Tablo 5 incelendiğinde İstanbul C1/+ Yabancılar İçin Türkçe Ders Kitabı'nda toplam 28 adet dinî bilgi tespit edilmiştir. Buna göre dinî bilgilerin tüm bilgilere oranı \%3,73 olarak bulunmuştur. Tablo 5 incelendiğinde 4. ünitede yer alan "Fatih Sultan Mehmet Mahkemede" adlı metnin en fazla dini bilgi içeren metin olduğu (11 dini bilgi, \%39,28) görülmektedir. Tablo incelendiğinde İstanbul C1/+ Yabancılar İçin Türkçe Ders Kitabı́ndaki okuma metinlerinin sadece 11 tanesinde dinî bilgi 
bulunmuştur. Okuma metinlerinin 25 tanesinde hiç dinî bilgi tespit edilmemiştir. Ünitelere göre dinî bilgi sayıları değerlendirildiğinde 4. ünitenin 13 adet $(\% 46,42)$ dinî bilgi ile en fazla dinî bilgi içeren ünitedir.

Okuma metinlerindeki dinî bilgilere birkaç örnek:

- Fatih, çıkardığı demir sopayı kadıya göstererek, "Eğer sen Allah'ın hükmünü uygulamayıp, elimi kesmeye beni mahkûm etmeseydin bununla başını paramparça ederdim." der. (s.72, Fatih Sultan Mehmet Mahkemede)

- Mimarın yaptığı bu cami gerçekten de 1766 depreminde yıkılmış, yerine Fatih Külliyesi yapılmıştır. (s. 72, Fatih Sultan Mehmet Mahkemede)

Aşağıdaki Tablo 6'da i̇stanbul C1/+ Yabancılar İçin Türkçe Ders Kitabı'nda bulunan okuma metinlerindeki sanatsal bilgi sayısı, frekans (f) ve yüzdelerle (\%) verilmiştir.

Tablo 6. İstanbul C1/+ Yabancılar İçin Türkçe Ders Kitabı'nda bulunan okuma metinlerindeki sanatsal bilgi sayısı, frekansları (f) ve yüzdeleri (\%)

\begin{tabular}{|c|c|c|c|c|}
\hline No & Ünite & Metin & Sanatsal bilgi sayısı (n) & Yüzde(\%) \\
\hline 1 & 1 & Saatin İcadı & 0 & 0 \\
\hline 2 & 1 & 24 Saat Yetmiyorsa & 0 & 0 \\
\hline 3 & 1 & Ünlü Bilim Adamlarının Çocuklukları & 3 & 1,25 \\
\hline 4 & 2 & Aşkın Kimyası & 2 & 0,82 \\
\hline 5 & 2 & Ünlü Aşıklar ve Aşk Mektupları & 22 & 9,20 \\
\hline 6 & 2 & Aşkın Sırrı & 0 & 0 \\
\hline 7 & 3 & $\begin{array}{l}\text { Büyük ikramiyeyi kazanıp sonra } \\
\text { kaybedenler }\end{array}$ & 2 & 0,82 \\
\hline 8 & 3 & Satranç ve Tavla & 3 & 1,25 \\
\hline 9 & 3 & Elmas Gerdanlık & 4 & 1,67 \\
\hline 10 & 4 & Arzuhalden Dilekçeye & 0 & 0 \\
\hline 11 & 4 & $\begin{array}{l}\text { İş Görüşmelerinde İş Verenler Nelere } \\
\text { Dikkat Eder? }\end{array}$ & 0 & 0 \\
\hline 12 & 4 & Fatih Sultan Mehmet Mahkemede & 6 & 2,51 \\
\hline 13 & 5 & Lumiere Kardeşler & 21 & 8,78 \\
\hline 14 & 5 & Susuz Yaz & 46 & 19,24 \\
\hline 15 & 5 & Yabancı Ülkelerde Yayınlanan Türk Dizileri & 13 & 5,43 \\
\hline 16 & 6 & Bilge ve Bilgelik & 0 & 0 \\
\hline 17 & 6 & Bilgi Teknolojisi & 0 & 0 \\
\hline 18 & 6 & Bilgi Toplumu ve Üniversiteler & 2 & 0,82 \\
\hline 19 & 7 & Sanat Nedir? & 29 & 12,13 \\
\hline 20 & 7 & Sanat Türleri & 22 & 9,20 \\
\hline 21 & 7 & Türk Süsleme Sanatları & 36 & 15,06 \\
\hline 22 & 8 & Suç Nedir? & 0 & 0 \\
\hline 23 & 8 & Adalet Nedir? & 0 & 0 \\
\hline 24 & 8 & Esaretin Bedeli & 5 & 2,09 \\
\hline 25 & 9 & Mizah Her Kapıуı Açar & 6 & 2,51 \\
\hline 26 & 9 & Mizah Türleri & 6 & 2,51 \\
\hline 27 & 9 & Hasan Kaçan & 10 & 4,18 \\
\hline 28 & 10 & Dünden Bugüne Para & 0 & 0 \\
\hline 29 & 10 & Türkiye'de Enflasyonun Tarihi Gelişimi & 0 & 0 \\
\hline 30 & 10 & Öğrenciler İçin Tasarruf Yöntemleri & 0 & 0 \\
\hline
\end{tabular}


Yabancılara Türkçe Öğretimindeki Ders Kitaplarındaki Okuma Metinlerinin Bilgi Türleri Açısından İncelenmesi ( İstanbul C1/+ Örneği)

\begin{tabular}{lllll}
\hline $\mathbf{3 1}$ & 11 & Dünyamız & 0 & 0 \\
$\mathbf{3 2}$ & 11 & Küresel Isınma Nedir? & 0 & 0 \\
$\mathbf{3 3}$ & 11 & Dünya'dan Mars'a & 0 & 0 \\
$\mathbf{3 4}$ & 12 & Gençlerin Medya Tüketimi & 0 & 0 \\
$\mathbf{3 5}$ & 12 & Mert'in Illetişim Serüveni & 1 & 0,41 \\
$\mathbf{3 6}$ & 12 & Internet ve Sosyal Medya Bağımlılı̆̆ı & 0 & 0 \\
Toplam & & & $\mathbf{2 3 9}$ & $\mathbf{1 0 0}$ \\
\hline
\end{tabular}

Tablo 6 incelendiğinde İstanbul C1/+ Yabancılar İçin Türkçe Ders Kitabı'nda toplam 239 adet sanatsal bilgi tespit edilmiştir. Buna göre sanatsal bilgilerin tüm bilgilere oranı $\% 15,94$ olarak bulunmuştur. Tablo 6 incelendiğinde 5. ünitede yer alan "Susuz Yaz" adlı metnin en fazla sanatsal bilgi içeren metin olduğu (46 sanatsal bilgi, \%19,24) görülmektedir. Tablo incelendiğinde İstanbul C1/+ Yabancılar İçin Türkçe Ders Kitabı'ndaki okuma metinlerinin sadece 18 tanesinde sanatsal bilgi bulunduğu göze çarpmaktadır. Okuma metinlerinin 18 tanesinde hiç sanatsal bilgi tespit edilmemiştir. Ünitelere göre sanatsal bilgi sayıları değerlendirildiğinde 7 . ünitenin 87 adet $(\% 36,40)$ sanatsal bilgi ile en fazla sanatsal bilgi içeren ünite olduğu belirlenmiştir.

Okuma metinlerindeki sanatsal bilgilere birkaç örnek:

- Nazım'ın şiirlerine konu olmuş Kerem ile Aslı, Tahir ile Zühre, Ferhat ile Şirin gibi: Nazım ile Piraye. (s. 38, Ünlü Aşıklar ve Aşk Mektupları)

- Ve bu filmindeki başarılı rolü için Türk Kadınlar Birliği tarafından Hülya Koçyiğit, yılın kadın sanatçısı seçildi. (s. 85, Susuz Yaz)

- Başında Martin Scorcase'nin olduğu "Dünya Sinema Vakfı" diye bir kurum var. (s. 85, Susuz Yaz)

- "Sanat" kelimesi genelde görsel sanatlar anlamında kullanılıyor. (s. 116, Sanat Nedir?)

- Göze güzel görünümler sergilemek, kulağa hoş sesler duyurmak ve ruhta heyecan yaratmak güzel sanatların amacıdır. (s. 120, Sanat Türleri)

Aşağıdaki Tablo 7'de İstanbul C1/+ Yabancılar İçin Türkçe Ders Kitabı'nda bulunan okuma metinlerindeki teknik bilgi sayısı, frekans (f) ve yüzdelerle (\%) verilmiştir.

Tablo 7. İstanbul C1/+ Yabancılar Için Türkçe Ders Kitabı'nda Bulunan Okuma Metinlerindeki Teknik Bilgi Sayısı, Frekansları (f) ve Yüzdeleri (\%)

\begin{tabular}{lllll}
\hline No & Ünite & Metin & Teknik bilgi sayısı (n) & Yüzde(\%) \\
\hline $\mathbf{1}$ & 1 & Saatin İcadı & 7 & 28 \\
$\mathbf{2}$ & 1 & 24 Saat Yetmiyorsa & 2 & 8 \\
$\mathbf{3}$ & 1 & Ünlü Bilim Adamlarının Çocuklukları & 2 & 8 \\
$\mathbf{4}$ & 2 & Aşkın Kimyası & 0 & 0 \\
$\mathbf{5}$ & 2 & Ünlü Aşıklar ve Aşk Mektupları & 0 & 0 \\
$\mathbf{6}$ & 2 & Aşkın Sırrı & 0 & 0 \\
$\mathbf{7}$ & 3 & Büyük ikramiyeyi kazanıp sonra & 1 & 4 \\
\hline
\end{tabular}




\begin{tabular}{|c|c|c|c|c|}
\hline & & kaybedenler & & \\
\hline 8 & 3 & Satranç ve Tavla & 0 & 0 \\
\hline 9 & 3 & Elmas Gerdanlık & 0 & 0 \\
\hline 10 & 4 & Arzuhalden Dilekçeye & 0 & 0 \\
\hline 11 & 4 & $\begin{array}{l}\text { İş Görüşmelerinde İş Verenler Nelere } \\
\text { Dikkat Eder? }\end{array}$ & 0 & 0 \\
\hline 12 & 4 & Fatih Sultan Mehmet Mahkemede & 0 & 0 \\
\hline 13 & 5 & Lumiere Kardeşler & 0 & 0 \\
\hline 14 & 5 & Susuz Yaz & 0 & 0 \\
\hline 15 & 5 & Yabancı Ülkelerde Yayınlanan Türk Dizileri & 0 & 0 \\
\hline 16 & 6 & Bilge ve Bilgelik & 0 & 0 \\
\hline 17 & 6 & Bilgi Teknolojisi & 0 & 0 \\
\hline 18 & 6 & Bilgi Toplumu ve Üniversiteler & 2 & 8 \\
\hline 19 & 7 & Sanat Nedir? & 0 & 0 \\
\hline 20 & 7 & Sanat Türleri & 2 & 8 \\
\hline 21 & 7 & Türk Süsleme Sanatları & 0 & 0 \\
\hline 22 & 8 & Suç Nedir? & 0 & 0 \\
\hline 23 & 8 & Adalet Nedir? & 0 & 0 \\
\hline 24 & 8 & Esaretin Bedeli & 4 & 16 \\
\hline 25 & 9 & Mizah Her Kapıyı Açar & 0 & 0 \\
\hline 26 & 9 & Mizah Türleri & 0 & 0 \\
\hline 27 & 9 & Hasan Kaçan & 0 & 0 \\
\hline 28 & 10 & Dünden Bugüne Para & 0 & 0 \\
\hline 29 & 10 & Türkiye'de Enflasyonun Tarihi Gelişimi & 0 & 0 \\
\hline 30 & 10 & Öğrenciler İçin Tasarruf Yöntemleri & 3 & 12 \\
\hline 31 & 11 & Dünyamız & 0 & 0 \\
\hline 32 & 11 & Küresel Isınma Nedir? & 0 & 0 \\
\hline 33 & 11 & Dünya'dan Mars'a & 1 & 4 \\
\hline 34 & 12 & Gençlerin Medya Tüketimi & 0 & 0 \\
\hline 35 & 12 & Mert'in İletişim Serüveni & 0 & 0 \\
\hline 36 & 12 & İnternet ve Sosyal Medya Bağımlılığı & 1 & 4 \\
\hline \multicolumn{3}{|c|}{ Toplam } & 25 & 100 \\
\hline
\end{tabular}

Tablo 7 incelendiğinde İstanbul C1/+ Yabancılar İçin Türkçe Ders Kitabı'nda toplam 25 adet teknik bilgi tespit edilmiştir. Buna göre teknik bilgilerin tüm bilgilere oranı \%1,66 olarak bulunmuştur. Tablo 7 incelendiğinde 1. ünitede yer alan Saatin İcadı adlı metnin en fazla teknik bilgi içeren metin olduğu (7 teknik bilgi, \%28) görülmektedir. Tablo incelendiğinde İstanbul C1/+ Yabancılar İçin Türkçe Ders Kitabı'ndaki okuma metinlerinin sadece 10 tanesinde teknik bilgi bulunmuştur. Okuma metinlerinin 26 tanesinde hiç teknik bilgi tespit edilmemiştir. Ünitelere göre teknik bilgi sayıları değerlendirildiğinde 1. ünitenin 11 adet (\%44) teknik bilgi ile en fazla teknik bilgi içeren ünitedir.

Okuma metinlerindeki teknik bilgilere birkaç örnek:

- Bu ilk saatler yüzyıllar boyunca zamanın ölçülmesi için kullanılan en yaygın araç olmuşlardır. (s. 10, Saatin İcadı)

- Bunun için ya çok büyük yapılması ya da başında her an birinin beklemesi gerekiyordu. (Kum saati hakkında) (s. 11, Saatin İcadı) 
Yabancılara Türkçe Öğretimindeki Ders Kitaplarındaki Okuma Metinlerinin Bilgi Türleri Açısından İncelenmesi ( İstanbul C1/+ Örneği)

Aşağıdaki Tablo 8'de İstanbul C1/+ Yabancılar İçin Türkçe Ders Kitabı'nda bulunan okuma metinlerindeki gündelik bilgi sayısı, frekans (f) ve yüzdelerle (\%) verilmiştir.

Tablo 8. İstanbul C1/+ Yabancılar İ̧̧in Türkçe Ders Kitabı'nda Bulunan Okuma Metinlerindeki Gündelik Bilgi Sayısı, Frekansları (f) ve Yüzdeleri (\%)

\begin{tabular}{|c|c|c|c|c|}
\hline No & Ünite & Metin & Gündelik bilgi sayısı (n) & Yüzde(\%) \\
\hline 1 & 1 & Saatin İcadı & 13 & 2,83 \\
\hline 2 & 1 & 24 Saat Yetmiyorsa & 40 & 8,73 \\
\hline 3 & 1 & Ünlü Bilim Adamlarının Çocuklukları & 9 & 1,96 \\
\hline 4 & 2 & Aşkın Kimyası & 1 & 0,21 \\
\hline 5 & 2 & Ünlü Aşıklar ve Aşk Mektupları & 4 & 0,87 \\
\hline 6 & 2 & Aşkın Sırrı & 31 & 6,76 \\
\hline 7 & 3 & $\begin{array}{l}\text { Büyük ikramiyeyi kazanıp sonra } \\
\text { kaybedenler }\end{array}$ & 26 & 5,67 \\
\hline 8 & 3 & Satranç ve Tavla & 8 & 1,74 \\
\hline 9 & 3 & Elmas Gerdanlık & 33 & 7,20 \\
\hline 10 & 4 & Arzuhalden Dilekçeye & 7 & 1,52 \\
\hline 11 & 4 & $\begin{array}{l}\text { İş Görüşmelerinde iş Verenler Nelere } \\
\text { Dikkat Eder? }\end{array}$ & 19 & 4,14 \\
\hline 12 & 4 & Fatih Sultan Mehmet Mahkemede & 3 & 0,65 \\
\hline 13 & 5 & Lumiere Kardeşler & 4 & 0,87 \\
\hline 14 & 5 & Susuz Yaz & 13 & 2,83 \\
\hline 15 & 5 & Yabancı Ülkelerde Yayınlanan Türk Dizileri & 8 & 1,74 \\
\hline 16 & 6 & Bilge ve Bilgelik & 2 & 0,42 \\
\hline 17 & 6 & Bilgi Teknolojisi & 6 & 1,31 \\
\hline 18 & 6 & Bilgi Toplumu ve Üniversiteler & 3 & 0,65 \\
\hline 19 & 7 & Sanat Nedir? & 4 & 0,84 \\
\hline 20 & 7 & Sanat Türleri & 2 & 0,42 \\
\hline 21 & 7 & Türk Süsleme Sanatları & 0 & 0 \\
\hline 22 & 8 & Suç Nedir? & 10 & 2,18 \\
\hline 23 & 8 & Adalet Nedir? & 0 & 0 \\
\hline 24 & 8 & Esaretin Bedeli & 30 & 6,55 \\
\hline 25 & 9 & Mizah Her Kapıyı Açar & 23 & 5,02 \\
\hline 26 & 9 & Mizah Türleri & 10 & 2,18 \\
\hline 27 & 9 & Hasan Kaçan & 2 & 0,42 \\
\hline 28 & 10 & Dünden Bugüne Para & 15 & 3,27 \\
\hline 29 & 10 & Türkiye'de Enflasyonun Tarihi Gelişimi & 13 & 2,83 \\
\hline 30 & 10 & Öğrenciler İçin Tasarruf Yöntemleri & 42 & 9,17 \\
\hline 31 & 11 & Dünyamız & 2 & 0,42 \\
\hline 32 & 11 & Küresel Isınma Nedir? & 3 & 0,65 \\
\hline 33 & 11 & Dünya'dan Mars'a & 5 & 1,09 \\
\hline 34 & 12 & Gençlerin Medya Tüketimi & 16 & 3,49 \\
\hline 35 & 12 & Mert'in İletişim Serüveni & 30 & 6,55 \\
\hline 36 & 12 & İnternet ve Sosyal Medya Bağımlılığı & 21 & 4,58 \\
\hline Toplam & & & 458 & 100 \\
\hline
\end{tabular}

Tablo 8. incelendiğinde İstanbul C1/+ Yabancılar İçin Türkçe Ders Kitabı'nda toplam 458 adet gündelik bilgi tespit edilmiştir. Buna göre gündelik bilgilerin oranı tüm bilgilerin $\% 30,55^{\prime}$ lik kısmını oluşturmuştur. 10. ünitede yer alan Öğrenciler İçin Tasarruf Yöntemleri adlı metin, Tablo 8'e göre en fazla gündelik bilgi içeren metindir (42 bilgi, \%9,17). 7. ünitede yer alan Türk Süsleme Sanatları, 8. ünitede yer alan Adalet Nedir?,7. ünitede yer alan Sanat Türleriadlı metinlerde hiç gündelik bilgiye 
rastlanmamıştır. Ünitelere göre gündelik bilgi sayıları değerlendirildiğinde 10 . ünitenin 70 adet $(\% 15,28)$ gündelik bilgi ile en fazla gündelik bilgi içeren ünitedir.

Okuma metinlerindeki gündelik bilgilere birkaç örnek:

- Kadın, birkaç saniye kafasında hesap yapmaya başladı. Sonunda tereddüt ederek cevapladı: "Tam olarak bilmiyorum ama dört yüz franka halledebilirim sanırım." (Sayfa 58, Elmas Gerdanlık)

- Madam Loisel, gerdanlığı arkadaşına geri götürdügünde kadın soğuk bir tavırla, "Daha önce geri getirmen gerekirdi, ihtiyacım olabilirdi." dedi. (Sayfa 59, Elmas Gerdanlık)

- Devletten aldığı yaşııık maaşıyla geçinen Sarıoğlu'nın evi yanınca köylüler aralarında topladıkları parayla evini tamir ettirmişler. (Sayfa 51, Büyük Ikramiyeyi Kazanıp Sonra Kaybedenler)

- Öğrenciler, öğretmenlerinin verdiği ödevi anlamaya çalışmaktadırlar. Mert de öyle... (Sayfa 197, Mert'in Illetişim Serüveni)

- Gün içinde yapacaklarınızı iyi planlayın ve bulunduğunuz şehirdeki en etkin toplu taşıma araçlarını kullanın. (Sayfa 170, Öğrenciler İçin Tasarruf Yöntemleri)

Aşağıdaki Tablo 9'da İstanbul C1/+ Yabancılar İçin Türkçe Ders Kitabı'nda bulunan okuma metinlerindeki bilgilerin epistemolojideki altı bilgi türü olan bilimsel bilgi, felsefî bilgi, dinî bilgi, sanatsal bilgi, teknik bilgi ve gündelik bilgi sayıları açısından incelemesi yapılmış, sonuçlar frekans (f) ve yüzde (\%) ile gösterilmiştir.

Tablo 9. Istanbul C1/+ Yabancılar İ̧in Türkçe Ders Kitabı'nda Bulunan Okuma Metinlerindeki Bilimsel Bilgi, Felsefí Bilgi, Dinî Bilgi, Sanatsal Bilgi, Teknik Bilgi ve Gündelik Bilgi Sayıları (f) Ve Yüzdeleri (\%)

\begin{tabular}{lll}
\hline Bilgi Türleri & $\mathbf{n}$ & $\mathbf{\%}$ \\
\hline Bilimsel Bilgi & 405 & 27,01 \\
Felsefî Bilgi & 344 & 22,94 \\
Dinî Bilgi & 28 & 1,86 \\
Sanatsal Bilgi & 239 & 15,94 \\
Teknik Bilgi & 25 & 1,66 \\
Gündelik Bilgi & 458 & 30,55 \\
& & \\
Toplam & $\mathbf{1 6 1 1}$ & $\mathbf{1 0 0}$ \\
\hline
\end{tabular}

Yukarıdaki Tablo 9 incelendiğinde İstanbul C1/+ Yabancılar İçin Türkçe Ders Kitabı'nda 405 adet bilimsel bilgi (\%27,01), 344 adet felsefî bilgi (\%22,94), 28 adet dinî bilgi (\%1,86), 239 adet sanatsal bilgi $(\% 15,94), 25$ adet teknik bilgi $(\% 1,66)$ ve 458 adet $(\% 30,55)$ gündelik bilgi bulunduğu 
Yabancılara Türkçe Öğretimindeki Ders Kitaplarındaki Okuma Metinlerinin Bilgi Türleri Açısından İncelenmesi ( İstanbul C1/+ Örneği)

görülmektedir. Kitaptaki toplam bilgi sayısı ise -daha önce de belirtildiği gibi- 1611 olarak bulunmuştur.

Aşağıdaki Tablo 10 'da ünitelere göre cümle ve bilgi sayıları, frekans (f) ve yüzde (\%) olarak verilmiştir.

Tablo 10. Ünitelere Göre Cümle ve Bilgi Sayıları (F) ve Yüzdeleri (\%)

\begin{tabular}{|c|c|c|c|c|}
\hline Ünite & Cümle Sayısı & $\%$ & Bilgi Sayısı (n) & $\%$ \\
\hline 1. Ünite & 155 & 9,62 & 186 & 12,40 \\
\hline 2. Ünite & 203 & 12,60 & 163 & 10,87 \\
\hline 3. Ünite & 186 & 11,54 & 119 & 7,93 \\
\hline 4. Ünite & 64 & 3,97 & 74 & 4,93 \\
\hline 5. Ünite & 167 & 10,36 & 162 & 10,80 \\
\hline 6. Ünite & 129 & 8,007 & 143 & 9,53 \\
\hline 7. Ünite & 125 & 7,75 & 150 & 10,00 \\
\hline 8. Ünite & 146 & 9,06 & 104 & 6,93 \\
\hline 9. Ünite & 103 & 6,39 & 102 & 6,80 \\
\hline 10. Ünite & 118 & 7,32 & 114 & 7,60 \\
\hline 11. Ünite & 72 & 4,46 & 77 & 5,13 \\
\hline 12. Ünite & 143 & 8,87 & 105 & 7,00 \\
\hline Toplam & 1611 & 100 & 1499 & 100 \\
\hline
\end{tabular}

Tablo 10'a göre cümle sayısı bakımından en zengin ünite 203 cümle $(\% 12,6)$ ile 2. ünitedir. 2. Ünitedeki bilgi sayısı ise $163(\% 10,87)$ 'dir. 2. üniteyi 186 cümle $(\% 11,54)$ ile 3. ünite izlemektedir. 3. Ünitedeki bilgi sayısı ise $119(\% 7,93)^{\prime}$ dur. Cümle sayısı en az olan üniteler ise 64 cümle $(\% 3,97)$ ile 4. ünite ve 72 cümle $(\% 4,46) 11$. ünitedir.

Okuma metinlerinin içerdiği bilgi sayısı bakımından en zengin ünite 186 bilgi ile $(\% 12,40) 1$. ünitedir. 1. üniteyi 163 bilgi $(\% 10,87)$ ile 2 . ünite ve 162 bilgi $(\% 10,00)$ ile 5 . ünite izlemektedir.

Ünitelerdeki toplam cümle sayısı 1611, bilgi sayısı ise 1499 olarak görünmektedir.

\section{Sonuç}

Yabancılara dil öğretiminde kültür ve bilgi kavramları oldukça önemlidir. Çünkü dil ile birlikte bu iki kavramın aktarımı gerçekleşmektedir. Bu açıdan bakıldığında yabancılara dil öğretiminde kullanılan ders kitaplarının ve metinlerinin bu noktalara dikkat edilerek hazırlanması aktarım sürecinin başarılı bir şekilde ilerlemesini sağlayabilir. Bu çalışma, İstanbul C1/+ Yabancılar İçin Türkçe Ders Kitabı'nda (12 ünite ve 36 okuma metni) yer alan bilgi türlerini tespit etmeyi bu yüzden amaçlamıştır. Araştırmanın sonucunda, bilgi içeren cümle sayısı 1611, bilgi türü açısından bakıldığında 1499 adet bilgi tespit edilmiştir. Bu oranın yabancılara Türkçe öğretimi açısından olumlu olduğu söylenebilir. "Elmas Gerdanlık" adlı metin en fazla cümle (111 cümle, \%6,89); "Küresel Isınma" Nedir? (21 cümle, \%1,30)adlı metin en az cümle içermektedir. En çok bilgi zenginliği bulunduran metnin 8. ünitede yer alan "Esaretin Bedeli" adlı metin olduğunu (78 bilgi, \%5,20); en az bilgi 
bulunduran metnin 4. ünitede yer alan "Arzuhalden Dilekçeye" (12 bilgi, \%0,80) adlı metindir. Ünitelere göre cümle sayıları değerlendirildiğinde, 2. ünitenin cümle sayısı bakımından en zengindir. 2. ünitede 203 adet cümle tespit edilmiştir. 2. ünitedeki cümle sayısının tüm kitaptaki cümlelerin sayısına oranı ise \%12,60 olarak hesaplanmıştır. Ünitelere göre bilgi sayıları değerlendirildiğinde ise 1. ünitenin bilgi sayısı bakımından en zengin ünite olduğu söylenebilir. 1. ünitede toplam 186 adet bilgi tespit edilmiştir. 1. Ünitedeki bilgi sayısının tüm kitaptaki bilgilerin sayısına oranı ise $\% 12,40$ olarak hesaplanmıştır. Üniteler açısından cümle sayıları ve bilgi türleri değerlendirildiğinde ritmik bir dağııımın olmadığı söylenebilir.

Bilgi türleri açısından bakıldığında İstanbul C1/+ Yabancılar İçin Türkçe Ders Kitabı'nda 458 adet $(\% 30,55)$ gündelik bilgi, 405 adet bilimsel bilgi $(\% 27,01), 344$ adet felsefî bilgi (\%22,94), 239 adet sanatsal bilgi $(\% 15,94), 28$ adet dinî bilgi $(\% 1,86)$ ve 25 adet teknik bilgi $(\% 1,66)$ bulunduğu görülmektedir. Onan ve Arısoy'un (2013) İlköğretim ikinci kademe Türkçe ders kitaplarında en fazla bilimsel bilgi türü, en az teknik ve dini bilgi türleri tespit edilmiştir. Bu sonuç, çalışmamızın sonuçları ile paralellik göstermektedir. Yabancılara dil öğretimi açısından değerlendirildiğinde bilgi türleri açısından dağııımın olumlu olduğu söylenebilir. Çünkü yabancı birinin dil öğreniminde en fazla gündelik ve bilimsel bilgi türü ile ilgili bilgilere sahip olması gerektiği söylenebilir.

\section{Kaynaklar}

Akarsu, B. (1998). Dil-Kültür Bağlantısı, İnkılap Kitabevi, İstanbul.

Bolay, S. H. (2007). Felsefeye Giriş. Ankara: Akçağ Yayınları.

Cevizci, A. (2010). Bilgi Felsefesi. i̇stanbul: Say Yayınları.

Çüçen, A. K. (2009). Bilgi Felsefesi. Bursa: Asa Kitabevi.

Kaptan, S. (1998). Bilimsel Araştırma ve İstatistik Teknikleri, Ankara: Tekışık Yay.

Karasar, N. (2005). Bilimsel Araştırma Yöntemleri. Ankara: Nobel Yayınevi.

Onan, B. ve Arısoy, M.A. (2013). Türkçe öğretiminde epistemolojik bir yaklaşım, Ana Dili Eğitimi Dergisi, 1(1), 77-91.

Onan, B. (2013). Dil Eğitiminin Temel Kavramları. Ankara: Nobel Yayınevi.

Öner, N. (1998). "Bir Bilgi Türü Olarak Din”. Felsefe Dünyası Sayı: 29

Tunalı, i. (2009). Felsefeye Giriş. İstanbul: Altın Kitaplar Yayınevi.

Yaylı, D. ve Bayyurt, Y. (Ed.) (2014). Yabancılara Türkçe Öğretimi: Politika, Yöntem ve Beceriler. Anı Yayıncılık, Ankara. 